\title{
Student Beliefs: Thought as a Mean to Improve Human Coexistence
}

\author{
Miguel Monroy Farías,", ${ }^{1, *}$ Mónica Díaz Pontones² \\ ${ }^{1}$ School of Higher Studies Iztacala, National Autonomous University of Mexico, México \\ ${ }^{2}$ Autonomous University of Mexico City, Mexico
}

Copyright $\odot 2018$ by authors, all rights reserved. Authors agree that this article remains permanently open access under the terms of the Creative Commons Attribution License 4.0 International License

\begin{abstract}
Based on the complexity theory, it is possible to understand the diversity of elements and connections involved in human coexistence. From the systemic point of view, the development of thought processes which are strategic, creative, critical or argumentative, is an element of dignified coexistence, because it favors dialogue, debate or consensus. But attitudes of respect, tolerance and support for human plurality in terms of ways of thinking, feeling and living are also essential. The research assumption is that teaching thinking skills and attitudes could lead to intelligent and respectful behavior in human coexistence. Specifically, college students' beliefs about the need to promote different ways of thinking were analyzed. This is a qualitative phenomenological research. Students from the National Autonomous University of Mexico (Group A) and the Autonomous University of Mexico City (Group B) were investigated about their beliefs on how the development of thought contributes to social coexistence, specifically about creative thinking, strategic thinking, critical thinking and argumentative thinking. Results: the beliefs of students who think creatively lead to a problem solving social interaction, or a thinking about a better world. Thinking in a convenient way allows you to combat violence or improve human communication. Thinking critically helps analyze whether actions are suitable for human coexistence and among others, if we reflect to analyze whether we act in a relevant way or on the importance of the benefits of the rest of the thinking skills and abandonment of mediocrity.
\end{abstract}

Keywords Student Beliefs, Thinking Skills, Cognitive Processes, Human Coexistence, Respect

\section{Introduction}

According to Wallon [1] in the phylogenetic process of the psyche, sensations, affections, emotions and feelings appear in subhuman organisms and occupy a place in the nervous system with relative autonomy. For Wallon, emotion and feelings are not exclusive human features, since their presence can be found in fish, reptiles, birds, mammals and even more noticeably in anthropoids. Wallon says that the protection of adults against the aggression of predators evidently triggers a defense through attack and annihilation. Darwin had already mentioned that adults violently protect the survival of the fittest. Unfortunately, in our daily human life, in addition to biological theory, the presence of a kind of social Darwinism is accepted. The behaviorism proposed by Skinner [2] admits so, and suggests that operant conditioning rather than natural selection is responsible for that. The nation, says Skinner, producing intelligent, energetic, brave, patriotic and benevolent citizens, shall prevail. In order to survive, it has been commonplace for economic groups in highly developed countries to subdue and exploit weak countries and people. In response, the dispossessed or those who see their life and cultural values threatened, also display violent behaviors, but are considered terrorists. Violence breeds violence and the party acting with greater violence wins. School can promote dignified human coexistence, but it is not always so. Adorno [3] condemns that school itself can lead to barbarism and domination when it prevents the construction of critical thinking.

Language, thought and social life are the distinctive features of the human species. In human development, emotion is compatible with the individual's interests and safeguard if it is able to pair with knowledge and reasoning, says Wallon [4]. Our emotions can have derivations favorable to coexistence, but can also have perverse consequences when they are not mediated or driven by intelligent actions. Emotions connect us with others, but must be guided by thought in order to tailor human relations for mutual advantage. In the absence of intelligent actions, the emotional dominance that characterizes the subhuman animal world prevails. When the fury of violence takes control, says Wallon [5], thinking is obscured and intelligent actions or decisions based on 
arguments for dignified coexistence become impossible to create. The above reflections justify the name of this paper: thought as a means to improve human coexistence.

The fragility of intellectual life is characteristic of people who have cultivated dilettantism, that is, people interested in personal commitments and responsibilities whose approach to social issues is superficial. The indigence of intellectual life, Wallon claims, distinguishes those who have cultivated a pusillanimous selfishness, that is, lack of courage to help people in situations of misery and suffering. Adorno [6] wondered how this world so developed in terms of science and technology, could, at the same time, suffer so much misery and massive annihilation of individuals. Adorno promoted an education designed to create democratic individuals.

According to Wallon [7], syncretic thought prevails in the early childhood stage of human development. Whereas, for Piaget [8] early childhood is the stage where the sensory input nourishes daily life knowledge. This is the spectator stage because mental processes or operations are only incipient or yet to be born. When an adult limits his knowledge to what he sees on television or the Internet; when he limits his knowledge to the discourse of politicians or teachers, he narrows his understanding to the product of his sense-perceptions. This adult lacks the ability or expertise to perform deductive or inductive processes, or a variety of intellectual functions, such as the analytical thinking that would allow him to look at things comprehensively to understand the complexity of a topic or an event, or the critical thinking that would enable him to question alleged certainties, or asses or argue situations or facts based on what is relevant, necessary or sufficient, thus preventing him from making valuable decisions for dignified coexistence.

For Wallon, syncretic thought is related to superstition, myths, luck and religious alienation. Remaining there during adult life is the expression of wishful thinking, of having an answer for everything, of solving the complexities of life simplistically, of remaining faithful to horoscopes or becoming involved with religious fanaticism. Syncretism, as mentioned by Huerta [9] places the person in an apparently invulnerable position, with complete certainty, and adds that prejudice or religious dogma render the effort to know a different truth useless. Syncretism blinds individuals to the ultimate consequences of the acts performed. There are those who immolate themselves by murdering many to allegedly secure their salvation. According to Piaget [10] this way of thinking remains in the adult because the transition from heteronomy to moral and intellectual autonomy has not taken place and, according to Wallon, because syncretic thinking has not been replaced by categorical thinking. This is what happens when school fails to promote the construction of different types of thinking such as the argumentative, creative, critical, analytical or strategic type in order to devise a social life without violence, without discrimination, or to solve problems through dialogue, debate or collaborative teamwork.

\section{Considerations on Critical Thinking for Social Coexistence}

According to Lipman [11] school does not encourage critical thinking about dehumanization, nor does it educate us to know our raison d'etre and for being in this world. Lipman, as well as Freire [12] emphasize the promotion of dialogue for fostering understanding and solidarity, and for building a more humane society. Meanwhile, Pérez [13] claims that the economic model subtly imposes uncritical eclecticism and the supremacy of single amorphous and weak thinking.

It is relevant that the teacher reflects on how to develop critical thinking to question politician corruption, social inequalities, injustice and violence in everyday life. The teacher needs to move away from converting students into beings skillful in easily accepting the thoughts of others, whether such thoughts come from politicians, the media, the Internet, or even from the classroom and the rules of coexistence established by the teacher. There are teachers who promote early adherence or submission to his or her way of thinking and acting. Levine and Pavelchak [14] mention that this is the case when the person modifies his own posture in favor of the group's vision, such as when the student easily changes his thinking to that of the teacher. Conformity is promoted in school when, through obedience, a person is required to submit to the authority's point of view. Failure by teachers to promote the construction of critical thinking prevents students from discovering false or prejudicial assumptions and makes it impossible for them to identify contradictions and inconsistencies in the teacher's thinking or that of others [15]. The same is true, as Adorno [16] stated that in daily life the poor are prevented from thinking by the discipline of others, the rich by their own.

Educating for critical thinking requires consolidating reflective and argumentative processes based on the strength of the reasons provided; calls for strengthening our decision-making skills in terms of what we think, decide, and do. Critical thinking, according to Paul and Elder [17] occurs with deep reasoning aimed at improving, enriching or enhancing the complexity of our knowledge of a situation, event, or subject.

The presence of naive, dependent, submissive and thoughtless students, citizens and professionals poses a danger to school, citizenship and work life due to the absence of critical thinking [18].

\section{The Research}

This work is interested in the understanding of the meanings that university students give to their experiences 
in the events of the diversity of processes, factors and conditions that influence their ways of thinking and the relevance of their thought processes to apprehend and interpret their subjective experience from their own frames of reference. In turn, the phenomenological approach emphasizes the analysis of the individual, the subjective experience, the perspective of the phenomena from the subjects and focuses on the knowledge of how people experience and interpret the social world they construct in interaction [19]. This is a phenomenological-qualitative case study where students' beliefs were analyzed with regard to thought as a means to improve human coexistence. Participants: Two groups of university students formed the target group of this research. On the one hand, in <group A>, 25 students from the National Autonomous University of Mexico (UNAM) of the School of Higher Studies Iztacala participated. The group consisted of 14 women and 11 men from the 3rd semester of the Psychology career. The age range is 22 and 25 years. Most students devote full time to university studies, only five of them work and study. The <group B> was integrated by 25 students of the Autonomous University of Mexico City, of the North Male Preventive Prison, Cuautepec, of the Law degree. The group was formed by 25 men, (UACM) who study the First Semester of Law. The age range is 25 and 40 years. Most of the students, 23, are engaged in training and studying at the same time. Data collection: The methodological strategies used in this research were: three direct observations in classrooms of each group; field journals; In-depth interviews and questionnaire of open questions applied to each one of the participants, as well as the elaboration of analysis matrices. The qualitative researcher's challenge is to analyze the data to understand the words of the participants [20]. Therefore, through research they were selecting, interpreting and relating the significant data to make sense of them. The analysis of the data was carried out based on the principles of ethnographic analysis, which implies the interpretation of meanings as Geertz points out [21]. Several analysis matrices were elaborated that made it possible to order multiple elements that interact with each other within a structure.

\section{Results}

The results obtained through the aforementioned methodological instruments are syntheses of the different meanings and signifiers that the participants gave to this research. The elaboration of meaning is a social process; it is an activity that always takes place within a cultural and historical context [22]. The senses and meanings are perceived and understood through an internal organization of the data, mediated by conceptual constructs and ways of seeing the world [23], which are made $<$ to account for certain aspects of reality> [24]. Various meanings and meanings that the participants expressed in relation to different thought processes for a better human coexistence are the following.

\section{Creative Thinking}

The most representative meanings of the participants of both groups are presented about their beliefs and representations about creative thinking. Regarding the meaning of "creative thinking", we can point out that there are no significant differences between the two groups. For the majority of students, thinking about creative means starting various cognitive abilities to solve a problem, generate new ideas or projects. In a timely manner, some of the members of group A, considered that the thinking of creative management is: a way of imagining solutions..., $a$ way of devising, imagining, innovating, solving..., when mental capabilities are put into practice to start new projects... While for the members of group B, creative thinking is: a way of getting to something original and unique..., when the mind is directed to building and not destroying..., to think of a different world, to escape the one we have..., having ideas leading to something new...

\section{What Actions May Be Created to Improve Coexistence?}

In relation to the actions of a creative thinking to improve human coexistence, we can find differences between both groups. Group A, focuses on improving communication, respect, interaction and social networks as various creative activities to promote better coexistence. According to student representations, thinking creatively can improve coexistence, because actions can be created for: - improving communication..., kindness and respect while interacting..., greeting people... even if you don't know them..., kindness and mutual respect..., using social media to convene others to participate in public events where the creation of different artistic and cultural manifestations is promoted..., respect and trust..., recreational activities... concerts, ...trade shows...

Group B focuses its meanings on fostering trust, respect, responsibility and avoiding violence towards the other. According to student representations, thinking creatively can improve coexistence, because you can create actions for: becoming aware about the goals that as citizens we shall have..., educating for respect and promoting respect for cultural diversity..., fostering coexistence through respectful interaction..., promoting accountability of each individual... as a means to create conditions that reduce homophobia, gender violence..., fostering solidarity...

Both groups agree that establishing respect... is essential for the improvement of coexistence.

Based on the student's beliefs, creativity leads to imagining new solutions, to innovating, to finding "the original", the unique thing, to building a different world and to doubt the certainty of our knowledge, something similar to De Bono proposal [25]. Students mention that creative thinking is necessary to improve communication, 
respect, trust, kindness, to greet the other. It is a challenge for school and governments to create conditions for social responsibility regarding dignified human relationships.

\section{Strategic Thinking}

Regarding the meaning of "think strategically", we can point out some significant differences in both groups. For example, for group A, strategic thinking focuses more on clarity before acting: ... having clarity about projects before acting..., looking for alternative and utopian methods..., deciding what actions to take in order to reach the objectives..., assessing the matter to see what kind of actions are the most appropriate..., thinking in an organized manner, organizing ideas..., thinking and planning strategically...

...While for group B, the strategic thinking revolves around the search for solutions, for example: analyzing the problem to see how to solve it..., searching for solutions, looking for different paths..., reasoning in order to find a solution..., finding solutions to a problem...

Given the strategies to combat violence we can point out that both groups agree that education is one of the most important means to reduce violence: Investing in the education of children, young people and adults..., an education towards developing complex thinking..., Supporting better education. But this is not done because education could open up more chances to combat the government.., An education that cultivates critical thought and awareness, to analyze what one does..., The crisis is terrible from the top (the president) down. An honest representative is needed, interested in the people's welfare and in solving poverty..., Building more schools and fewer prisons.., Promote reading; reading workshops, reading centers to read and understand who there is so much crime and how to reduce it..., Decent and well paid work prevents crime...

The students believe that strategic thinking consists in seeing the problem clearly before acting, in the search for alternative methods, among others, and choosing pertinent actions. Vygotsky [26] suggested the need to think before acting and to self-regulate actions to eventually assess the goals achieved. The challenge in school is to promote strategic thinking to achieve coexistence, solidarity and cooperation. The students propose to invest more in education in order to reduce violence; to develop critical awareness; honest politicians; promoting dignified work to prevent crime and violence. Unfortunately the national educational system is managed by a politician, not by an education authority.

\section{Critical Thinking}

Below are presented more representative meanings of the participants of both groups about their beliefs and representations around critical thinking. Regarding the meaning of "thinking critically", we can point out some significant differences in both groups. For example for group A, critical thinking focuses more on the use of cognitive skills, while group B focuses more on pointing out attitudes.

Group A students express their views about critical thinking as follows: It's thinking analytically about what I do, and if that is appropriate.... It means to reflect on a situation and see if is valid..., It's expressing my opinion with a qualifying adjective..., To think critically one needs to observe, analyze, reflect to provide a mature and true assessment..., It's observing the characteristics of something/someone and having an objective opinion... For example students of group B believe what to think critically it's refraining from rushing into accepting something, but respecting the opinions of others..., It's teaching without prejudice in order to provide a correct answer...

With regard to the beliefs of what it means and implies a critical judgment and its exemplification we can mention that there are differences in the meanings granted by both groups. Group A gives examples of critical judgments, using more frequently authorities such as parents and teachers, while members of group B offer examples in relation to political authorities.

Group A: My teachers are far from know exactly how to educate us as critical thinkers..., We have teachers who neglect their personal appearance..., ...neither do they have diversity in teaching methodologies..., They teach with simple and repetitive examples, without insight into the complexity of knowledge..., If my mother asks me to do her a favor, I do it, but if I ask her to do me a favor, she doesn't do it, I think it should be reciprocal... Examples of group B: The city Mayor just can't provide a real and intelligent response to the pollution problems in Mexico City.... If there was a critical personal judgment as to our politicians, they would stop being corrupt...

To think critically, from the students' beliefs, is to think analytically; to question the relevance and validity of what is done; to observe and reflect in order to reach a certainty; to refrain from promptly accepting the opinions of others; to oppose intellectual conformism; to encourage them to question, to identify assertions based on prejudice and to guide them to interpret, analyze, assess and make inferences [27]. The students feel that teachers fail to make critical judgments, fail to develop critical learners, lack diversity of teaching methods, and use simple and repetitive examples.

\section{Thinking as Reflection}

In the most representative meanings of the participants of both groups about their beliefs and representations in relation to thought as reflection, there are no significant differences. Group A students have the belief that thinking as a reflection: It's thinking twice or more, until one is 
sure..., It's a kind of metacognition, thinking about thinking..., It refers to thinking about why, how or the source of a certain topic... While for group B: It's using awareness..., it's analyzing deeply, to meditate..., and it's analyzing the mistakes of a person or his/her good deeds...

To the beliefs of why there are no reflexive solutions to various problems such as low wages or pollution. We can point out that the participants of both groups consider that the politicians and their corrupt forms are responsible for not solving these problems. It is interesting to know that the reflection of both groups focuses on the person and the actions of politicians. Some of the students' beliefs are as follows: The pollution situations doesn't improve because of greedy politician embezzlement..., There are abusive, greedy, ignorant officials, and it is not possible to build hospitals, schools, reduce poverty, create more jobs, lower gas prices..., Because politicians seek only self-enrichment..., Because politicians don't provide what everyone deserves..., Because corruption is in the politicians, they are not interested in fighting people's ignorance, the imposition of a certain culture by the State... Because politicians are selfish, they only think about their personal benefit, not of the people that keep them alive..., Due to bad investment of money, starting with politicians..., Because politicians are corrupt...

On the concept of reflecting, the students believe that it is a kind of metacognition related to learning to think, to becoming aware in order to analyze errors or good deeds or actions of daily life. According to student reflections, there is no improvement in air pollution ${ }^{1}$ because politicians keep the money, are abusive, greedy, corrupt, selfish and ignorant, seeking only self-enrichment. Those who stand as representatives of citizens have a disgraceful image.

\section{Learning Based on the Solution of Problems}

Below are two questions that encompass the most representative meanings of the participants of both groups about their beliefs and representations in relation to learning based on the solution of problems. As for the meaning given by students of group $\mathrm{A}$, we can point out that learning to solve problems requires a series of cognitive tools that allow, on the one hand, to identify and analyze different elements, processes or determinants of a problematic event, and on the other hand, to carry out a synthesis in order to glimpse different ways of solution to the problem. While for group B participants, learning based on solving problems restricts them to find practical solutions to the problem. In these solutions there is an interest in not generating interpersonal conflicts.

Beliefs of group A: It's a complex process, depends on personal experiences and the knowledge previously

\footnotetext{
${ }^{1}$ From April 6 to July 1, 2016, car use in Mexico City was restricted due to the high levels of air

pollution.http://www.eluniversal.com.mx/articulo/metropoli/cdmx/2016/ 04/6/publican-programa-para-contingencias-ambientales
}

acquired..., - It's having cognitive tools and knowing how to use them to solve problematic situations..., It's the ability to confront and accept reality making sense of and finding a practical solution to the situations we face on a daily basis... Group B beliefs: It's analyzing our knowledge, increasing it or changing it to solve problems.... It's solving an unknown to reach an agreement, without creating irritation or violence.... It's not to despair and to think clearly to find answers...

Participants of both groups agree that the way to resolve the corruption of the rulers in our country, falls on citizen initiatives to monitor the performance of politicians, greater intervention by society in decision making and in the monitoring of actions of politicians and governors, but also, that it is from education throughout life that corruption can be combated. Beliefs of the group A: By supporting the creation of citizen initiatives but approved and complied with by politicians..., By withdrawing politician immunity when they are corrupt..., The head, the President, must set the example and demand better performance from other officials..., Through educating, exercising moral and ethical values..., We need greater social participation, greater commitment to take part in political issues... Group B beliefs:: First, by beginning with one's self, abandoning corruption..., When one's rights are not sold or betrayed..., Removing from the government any corrupt and selfish individual..., Removing all corrupt persons, making a thorough cleansing of people. Throw out everyone who has done things against the laws..

Learning to solve problems, from the students' beliefs, is to make sense of and solve everyday situations, is to analyze the knowledge they have to increase or change such knowledge, and is to use cognitive tools to solve problematic situations. Learning to solve problems is linked to other types of learning, for example strategic learning, needed when considering ways to find solutions, critical learning, required to assess and make decisions, discovery learning, cooperative learning, when mutual help is needed to achieve results and, argumentative learning, to support the progression of learning. The way to solve corruption among government leaders, based on the students' beliefs, is to move away from corruption, to withdraw politician immunity when they commit wicked acts, and to politicians in moral values, but also to expel every corrupt politician. Although it is a complex issue, the actions to be undertaken arise when there is clarity on how to solve this problem.

\section{Beliefs about Being a Student}

The construction of thought processes for the improvement of human coexistence, among others, depends on how students have lived their experience in school situations. They analyze beliefs in relation to the educational level in which they had the best experience; the educational level in which it was his worst experience and 
beliefs on how his experience as students could better.

a) Beliefs about their best educational level. For group A participants, the most positive experience for students is in the basic and upper secondary levels, while for students in group B, they place their best experience in higher education. Examples of beliefs in students of group A: In elementary school, extrinsic motivations; in junior high and high school mere requirement and then a desire for personal improvement...; my best friends are from elementary school and high school..:, While for students of group B, their beliefs refer to: In college, a certain taste for the educational model and personal construction..., In college exciting and pleasant ..., To know that I need to develop a complex judgment/opinion and see others as my partners, in college..., It was not until college that I learned to see my limitations and that I'm walking towards human development..., In college I have learned to learn what I am every day...

Based on their representations, being a college student has been the best experience for their personal and professional construction. However, the percentage of students that reach college is low. By $201544 \%$ of people between 15 and 24 years old attended some type of school ${ }^{2}$. More than $50 \%$ had already dropped out due to financial problems, because they did not see the point of it, or because they didn't like it.

b) Beliefs about the educational level in which they had the most negative or unfortunate experience as students. In both groups the participants locate the most unfortunate experiences in the basic and upper secondary levels. In group A students conceive that:... when I was in 6th grade my mother died..., - In elementary school I failed 4th grade, in junior high I broke my fingers..., Having teachers not interested in their work, who missed classes, who did not prepare their classes..., Wasted time in the classroom..., In elementary school, there was a parent education program, I never met my father and I was excluded from many of those programs... Today my daughters endure it too... Beliefs of students of group B Junior high, in a rehabilitation center ... not pleased with high school at all..., When in 6th grade my teacher told me to "memorize the answers to a questionnaire" and I was very afraid of him.., - The worst was breaking with friends in Junior high...

Negative experiences due to death of relatives, health issues and, unfortunately, due to the lack of responsibility and commitment by teachers encourage students to learn, especially before college.

c) Beliefs about how they can improve as students. Representations of students of group A, indicate... By practicing critical thinking, by improving my academic performance and effort...enhancing my academic skills...By constructing my human condition, by developing self-knowledge, being self-critical..., By being

\footnotetext{
${ }^{2} \mathrm{http}: / /$ cuentame.inegi.org. $\mathrm{mx} /$ poblacion/asistencia.aspx?tema $=\mathrm{P}$
}

more organized, by remaining constant in classes..., By no longer being a teaser... by talking less in class, by paying more attention... Beliefs of students of group B: By moving away from conformism, mediocrity, practicing self-criticism..., By engaging in constructive activities in the search of purpose in life..., by avoiding what's negative for society, for me..., Readiness to listen to what teachers say..., With tolerance and patience...

Their beliefs about what they could improve as students refer to abandoning mediocrity, improving academic performance, fostering critical thinking and self-criticism. But also avoiding what's negative for society and being tolerant of others, that is, respecting others.

\section{Live and Work as a Team}

The human being is distinguished from other species by their ability to think and to live in society. The different expressions of thought can generate rationalities that favor the improvement of human coexistence and shared and collaborative work. Selfishness, the belief of unfounded superiority, discrimination, exclusion and lack of respect for diversity, do not make it possible to improve life together or share benefits for all. Participants of group A, believe that there is not always a favorable coexistence, nor a life in a team, be it in the family, at school or at work, as exemplified in the following beliefs: Because the ideals of the economic system favor individualism..., Lack of disposition, difference of ideas, methods, emotional disorders, lack of knowledge, lack of group empathy..., Because we have different opinions and no one wants to give in... In a similar way the participants of the group $\mathrm{B}$ conceive that coexistence is problematic for various reasons (irrational): Maybe because of ego, because one is not always willing to accept the contributions of others, as if only us were always right. Sometimes there are lazy people in the team, they are not interested and leave the work to others..., Lack of communication, incompatible interests and egocentrism..., Because there are many opposing opinions... many believe they are always right and then selfish conflicts arise..., Teamwork is not always possible due to egocentrism, protagonism, selfishness, the desire to control and the inability to accept mistakes or criticism about what we do...

We have started from the premise that thinking skills can favor human coexistence, solidarity and a life without violence; This is what Group A participants believe, because they consider that working as a team has the following senses: It's building upon the skills, abilities and knowledge of others..., It's contributing the knowledge of each participant for the group to work..., It's listening to the opinion of others and not leaving out my opinion..., It's sharing our ideas to organize a better idea... Group B participants allude to pacifism and consider it as a difficult undertaking, perhaps because they have de violence experiences. In timely manners they believe that working 
in teem have means such as it's doing something peacefully, in a solidarity way, with more people..., It's using communication and compatibility of interests.... But it's a very difficult job..., It's working as a group of people, as an artistic ensemble...

Teamwork, students mention, promotes communication, attitudes of solidarity, personal ideas, knowledge and skills are shared. Each one contributes ideas and at the same time learns from others. However, selfishness, the desire to control others, the lack of willingness to listen to others, and individualism prevent teamwork. The teacher's task is teaching to students to discuss different opinions, listening to others and having flexibility to accept the most compelling reasons on the subject being discussed, analyzed or planned.

\section{Discussion}

The meaning of the development of thought is as a guide to meaningful actions. The students of Group A and B believe that thinking creatively allows generating programs to improve human development, they believe it is possible to find solutions to social, political or cultural problems, and among other beliefs, they assume that creative thinking fosters the generation of new projects. Also and without great differences between the beliefs of both groups, they believe that thinking strategically is a way to imagine processes to promote coexistence. The beliefs of both groups agree on the need for the educational system to have the intention of developing strategic thinking to foster coexistence, solidarity and cooperation. Thinking critically encourages reflection to denounce corruption and violence that damage human relationships. University students in freedom - Group A - consider that critical thinking is about developing skills to analyze the validity of knowledge and believe that teachers are far from teaching to think critically. While students in Prison - Group B - consider that the political authorities do not have a critical conscience of their projects or reflect to look for pertinent solutions to social problems. Both groups believe that the rulers lack skills and attitudes to solve social problems and that they do not seek cooperation or solidarity to improve the conditions of coexistence. Both groups believe that if the teachers propose it, they can make teaching and learning possible to learn to learn, to discuss critically and to argue decision-making. They also believe that the challenge for teachers is to support them to abandon mediocrity, to teach them to live and work as a team, and to encourage them to fight against the individualism of the economic system, as well how to promote learning to think so that their actions in everyday life are smart. The economist Richard Thaler, was awarded the 2017 Nobel Prize in Economics, for highlighting the rationality and psychological elements that enrich decisions, actions and results in economic matters in favor of the majority.
Some small differences: Students of Group B believe that their best stage of studies has been the University, because they have increased their ways of thinking and above all their attitudes of respect and solidarity. It is encouraging that UACM gives them the opportunity to study a university degree because they are rethinking their actions in favor of human coexistence. Group A students consider that their best experience was in the first educational levels. Based on their later experiences, they believe that educational improvement requires more honest teachers that they listen to them, that they respect them and that they commit themselves to teaching that makes learning possible. However, it is also true that teachers not always respond personally to those who need it because they are responsible for too many students, because of bureaucratic burdens from schools or because academic programs are too heavy, but also, as a result of their professional poverty.

Research results indicate that disregard for school activities, aggression among students, indiscipline, lack of relevant interaction or lack of self-esteem are examples of lack of respect for school regulations, communication with others or poverty in individual development. Felix, Soriano and Godoy [28] suggest improving school climate and promoting responsibility for coexistence. Winner [29] says, the malady that afflicts young people is aggressive disrespect. Caballero [30] seeks to promote social coexistence based on education for peace.

The issue of respect appears in the generality of the data that was collected in the interviews, in the questionnaires and in the field diaries of the students of both groups. For example, they believe in "kindness and respect while interacting...", "mutual respect...", "respect and trust...", "respect for cultural diversity", "but respecting the opinions of others...". One cause of social decomposition is the lack of respect for others. Respect has been considered as the mother of all virtues [31]. Respect, according to Vilchis [32] is an essential element for coexistence and social cooperation. Social responsibility, along with honesty, makes trust between people possible. It is not enough to respect the rights of each person, responsibility and commitment in social action is a necessary complement. An individualistic stance is closer to arrogance, personal privilege and against a dignified life for everyone. Subjectivity shall give way to intersubjectivity. It's the passage from anarchy to democracy.

Lack of respect is expressed through crime, violence, terrorism, or corruption from both public authorities and political, economic, religious or school groups. According to Transparency International [33] corruption occurs when rights are violated in a flagrant and unpunished manner. Mexico, in 2014 had a Corruption Perceptions Index of 35 on a scale of 1 to 100 [34]. According to Transparency International y Transparencia Mexicana, in 2015, of 34 countries of the Organization for Economic Co-operation 
and Development (OCDE) México ranked 34th on the Perception of Corruption Index [35]. According to The Institute of Economics and Peace violence and its brother drug trafficking, in 2015 as an example, the economic costs of violence were very high [36]. Some articles of The New York Times that exemplify the enormous corruption and violence in Mexico are: Corruption at a Level of Audacity 'Never Seen in Mexico [37] where it is commented that governors accused of corruption have fled the country and have been imprisoned in Guatemala, in Italy and in Panama. In the article $A$ Scion of Mexico Fights Corruption, and Becomes a Target [38] it is commented that in Mexico, "if you fight corruption, corruption will fight you", and talks about the persecution that the government of Peña Nieto holds against the creator of Mexicans against Corruption and Impunity. One more example, Mexico is among the three countries worldwide where they kill journalists: 'It's Easy to Kill a Journalist' [39]. Murders of journalists in Mexico go unpunished [40]. Corruption and violence are far from human respect and are also manifestations of the lack of skills to think for the benefit of all. They dominate pride, greed, arrogance. Emotions direct human behavior and thought is subject to them. Our thesis is that thought analyzes, reflects, creates strategies, makes intelligent decisions for the good of all and then all the emotional support necessary to carry it out.

Based on thinking skills it is possible to recognize, value and respect the feelings, interests, beliefs, needs of others. Each person is unique and each deserves a dignified life. The autonomy of people needs to be respected, and that of those who are not autonomous, such as children or people with special needs, they must be protected from any injustice or inequity. Based on Heidegger's interpretation of Kant's ethics; respect is manifested when one is responsible towards oneself and towards others [41]. In this period, moral values and respect for people are being lost [42]. Respect has been transmitted in many cultures as an important universal value fundamental for their survival.

Teaching responsibility is present when its actions bring benefits; when teaching is valuable for the human education of students. This behavior is a sign of appreciation and respect for the social and professional development of the teacher's students. The United Nations Educational, Scientific, and Cultural Organization [43] promote culture and education based on democratic principles of dignity, equality and mutual respect of men. The agency calls upon joint respect because it favors mutual aid, justice, peace and the well-being of humanity. UNESCO requires that education in each country includes respect for the dignity and rights of each individual, i.e., promoting the development of thinking, learning to think, learning to learn, among others. Based on cognitive skills the relevance of respect between men in daily life can be substantiated, because thinking creates opportunities for dialogue, debate, consensus or argumentation.

To close: reason versus duty. As indiscipline is associated with violence, institutional and social teacher controls punish and penalize the offender. In the classroom, disrespect is linked to indiscipline, to disobeying the rules, such as keeping quiet, staying put, not interrupting teacher or peers. Students are expected to respect institutional regulations, but unfortunately without analyzing, reflecting or understanding how valuable they are for respect and dignified social coexistence. When respect is taught as a duty, you must respect, you must be honest... one does not reflect, analyze, or substantiate why one should respect. This work looks for an education that fosters the development of thinking skills to seek and find compelling reasons to justify and substantiate how valuable is respect for human coexistence. Using must, you must, and we must prevents students from thinking about, justifying or rationalizing the importance and need of having to or not having to do something, that is, it prevents them from justifying, finding the relevance, significance or value of something, instead of reducing such must or have to because of fear to punishment or moral guilt.

This is important to teach to think creatively, strategically, critically, it is necessary to make it possible for students to learn to solve problems, to work as a team, to build respect into human coexistence, thus it is valuable to criticize the social violence and improving the relationship between teachers and students.

\section{REFERENCES}

[1] H. Wallon. Los orígenes del carácter del niño. Ediciones Nueva Visión. Buenos Aires, 80-81, 1975.

[2] B.F. Skinner. Sobre el conductismo. Editorial Planeta, Madrid. 1974.

[3] Th. W. Adorno. Educación para la emancipación. Morata, Madrid. 1998.

[4] H. Wallon. Los orígenes del carácter del niño. Ediciones Nueva Visión. Buenos Aires, 78, 1975.

[5] H. Wallon. Los orígenes del carácter del niño. Ediciones Nueva Visión. Buenos Aires, 1975.

[6] Th. W. Adorno. Educación para la emancipación. Morata, Madrid,. 1998.

[7] H. Wallon. Los orígenes del carácter del niño. Ediciones Nueva Visión. Buenos Aires, 1975.

[8] J. Piaget. El nacimiento de la inteligencia en el niño. Grijalbo, México. 1990.

[9] J. Huerta. "Pensamiento sincrético y diferenciado en la solución de problemas". Online available from: $\mathrm{http}: / /$ publicaciones.anuies.mx/acervo/revsup/res036/txt4.ht $\mathrm{m}, 2008$.

[10] J. Piaget. El nacimiento de la inteligencia en el niño. Grijalbo, México. 1990. 
[11] M. Lipman, La filosofía en el aula, Ediciones de la Torre, Madrid, 1998.

[12] P. Freire, Pedagogía del oprimido, Siglo XXI, Editores, México, 1994.

[13] A. Pérez, La cultura escolar en la sociedad neoliberal, Morata, Madrid, 1999.

[14] S. Moscovici J. M. Levine y M. A. Pavelchak, "Conformidad y Obediencia", in S. Moscovici, Psicología Social tomo I, Paidos, México, 41-70.

[15] M. Monroy, Formación y representaciones docentes. UNAM, FESI. México. 2014.

[16] Th. W. Adorno. Educación para la emancipación. Morata, Madrid,. 1998.

[17] R. Paul, y L. Elder, Estándares de competencia para el pensamiento crítico". In Fundación para el Pensamiento Crítico. Online available from www.criticalthinking.org, 2005

[18] M. Monroy, Formación y representaciones docentes. UNAM, FESI. México. 2014.

[19] M. Díaz Pontones, L.A. Mora Gutiérrez y N. Bidault Mniszek, 2013, p31-Condiciones y Retos que enfrenta el Estudiante Universitario Externado. México, UACM. PESCER.

[20] B. G. Glaser \& A. L. Strauss, Discovery of grounded theory, Chicago, Illinois: Aldine, 1967.

[21] C. Geertz. La interpretación de las culturas, Gedisa, España, 1987.

[22] L. S. Vygotsky, El desarrollo de los procesos psicológicos superiores, Grijalbo, Barcelona, 1979.

[23] J. Brunner. Acción, pensamiento y lenguaje, México, Alianza Editorial, 1984.

[24] P. Willys. Culture, Media, Language, Londres, Hutchinson, 1980. [26]

[25] E. De Bono, El pensamiento paralelo, Paidos, México, 2000.

[26] L. S. Vygotsky, El desarrollo de los procesos psicológicos superiores, Grijalbo, Barcelona, 1979.

[27] M. Monroy, Formación y representaciones docentes. UNAM, FESI. México. 2014.

[28] V. Félix, M. Soriano, C. Godoy, Un Estudio Descriptivo sobre el Acoso y Violencia Escolar en la Educación Obligatoria". Escritos de Psicología - Psychological Writings, vol. 2, núm. 2, abril, 2009, pp. 43-51, Universidad de Málaga.

[29] L. Winner. Confronting the culture of disrespect, Tech Knowledge Revue, 2.3, December 21, 2000. Online available from:

http://www.netfuture.org/2000/Dec2100_115.html
[30] M. J. Caballero, Convivencia escolar. Un estudio sobre buenas prácticas. Revista de Paz y Conflictos, núm. 3, 2010, 154-169, Universidad de Granada.

[31] H. Dietrich, La importancia del respeto en la educación, revista Educación y Educadores, Online Available núm.7, 2004, 221-228. Online available from: http://www.redalyc.org/articulo.oa?id=83400715

[32] X. Vilchis, La Importancia del Respeto como Valor Fundamental de la Responsabilidad Social, Revista Razón y Palabra. Online available from: http://www.razonypalabra.org. mx/fcys/2002/julio.html

[33] MEXICO. Online available from https://www.transparency.org/country/MEX

[34] Índice de Percepción de la Corrupción 2015: Enfoque para México. Online available from: https://issuu.com/transparenciamexicana/docs/informe_ipc 2015

[35] México, el más corrupto de los 34 miembros de la OCDE: Índice de percepción de la corrupción. http://www.animalpolitico.com/2016/01/mexico-el-mas-cor rupto-de-los-34-miembros-de-la-ocde-indice-de-percepcion -de-la-corrupcion/

[36] The Institute of Economics and Peace: Global Peace Index, 2017. Online available from:

http://visionofhumanity.org/app/uploads/2017/06/GPI-2017 -Report-1.pdf

[37] Corruption at a Level of Audacity 'Never Seen in Mexico. Online available from:

https://www.nytimes.com/es/2017/04/19/mexico-gobernado res-corrupcion-impunidad-duarte/

[38] A Scion of Mexico Fights Corruption, and Becomes a Target. Online available from:

https://www.nytimes.com/2017/08/30/world/americas/mexi co-claudio-gonzalez-laporte.html

[39] It's Easy to Kill a Journalist. Online available from: https://www.nytimes.com/2017/04/29/world/americas/verac ruz-mexico-reporters-killed.html

[40] Asesinatos de periodistas en México quedan impunes. Online available from:

http://www.animalpolitico.com/2017/04/asesinatos-periodis tas-mexico/

[41] X. Vilchis, La Importancia del Respeto como Valor Fundamental de la Responsabilidad Social, Revista Razón y Palabra. Online available from:

http://www.razonypalabra.org. mx/fcys/2002/julio.html

[42] J. L. Valdez, Los valores éticos en adolescentes mexicanos", Revista de Enseñanza e Investigación en Psicología, Vol. 8 (2), 2003, 245-255.

[43] UNESCO, Declaración Universal sobre el Genoma y Derechos Humanos, Online available from: http://portal.unesco.org/es/ev.php-URL_ID $=13177 \&$ URL DO=DO TOPIC\&URL SECTION=201.html 